\title{
Effect of Season, Heat Clarification Temperature and Ripening of Cream on Color Parameters of Ghee
}

\author{
Sonia Mor*, Vivek Sharma, P.S. Minz and Navdeep Nain
}

Division of Dairy Chemistry, National Dairy Research Institute, Karnal (Haryana), India

*Corresponding author

\section{A B S T R A C T}

Keywords

Ghee, Color value,

Season, Whiteness index

Article Info

Accepted:

04 September 2018

Available Online:

10 October 2018

The objectives of this study were to evaluate the effect of season, heat clarification temperature and ripening of cream on the color attributes L [lightness (100: white, 0: black), a (+: red, -: green) and b (+: yellow, -: blue)] and Yellowness and Whiteness Index was observed. It was observed that effect of season was visible on the color value $a, b$ and Yellowness Index of cow ghee and buffalo ghee whereas seasonal variation did not make any significant difference on the color value (L) and Whiteness Index. No significant effect of ripening of cream and clarification temperature was observed on color value of ghee samples. The results showed that highest color value (L) for cow ghee was observed in month of Dec-Jan (79.02 \pm 1.59$)$ and for buffalo ghee in August-September $(81.95 \pm 0.637)$, color value (a) in the month of October-November $(-14.38 \pm 0.48)$ and February-March (-5.08 \pm 0.291$)$, color value (b) in December-January $(77.56 \pm 1.12$ and $11.77 \pm 1.094)$, Yellowness Index in February-March $(88.03 \pm 0.95)$ and December-January (14.38 \pm 1.310$)$, Whiteness Index in October-November (21.55 \pm 2.69$)$ and February-March (80.16 \pm 0.757$)$, respectively.

\section{Introduction}

Ghee, widely considered as the Indian name for butter fat, is usually prepared from cow milk or buffalo milk or a mixture of them. Ghee production forms the largest segment of the milk consumption and utilization pattern in India. It is the second largest consumed dairy product in India after liquid milk. It has been reported that about $30-35 \%$ of milk produced in India is converted into ghee (Pawar et al., 2014). About 60-70 \% of the total ghee produced is used for direct dressing, about 15$20 \%$ for cooking and frying of foods and approximately 5-7\% is used in religious rites (Rajorhia 1993). Ghee contributes significantly towards nourishment of people of all age groups. It is a good source of fatsoluble vitamins (A, D, E and K) and essential fatty acids (Rangappa and Achaya 1974). These days, cow ghee use is becoming popular among the consumers. Every consumer is also interested in the purity of cow ghee. The parameters based on physico-chemical constants are not capable of providing this assurance to the consumers, so different works have been conducted by various authors on the basis of color parameters of ghee to check 
purity and adulteration of ghee. So for that purpose, in present study different factors affecting the color parameters of ghee like effect of ripening and non-ripening of cream, heat clarification temperature and seasonal variations were studied.

\section{Materials and Methods}

\section{Collection and preparation of samples}

Cow and buffalo milks used for the preparation of respective ghee samples were collected bimonthly up to complete eight months (in August-September, OctoberNovember, December-January and FebruaryMarch) from the Livestock Research Centre, NDRI, Karnal. Samples of cow/buffalo ghee were prepared by creamery butter method (De, 2010).Soon after the collection of milk samples, these were warmed to $40^{\circ} \mathrm{C}$ and separated into cream using mechanical cream separator. The cream was pasteurized at $77^{\circ} \mathrm{C}$ for 5 minutes, cooled to room temperature and it was separated into two batches.

One batch was ripened using the culture M167 taken from NCDC, NDRI at $21^{\circ} \mathrm{C}$ for $14 \mathrm{hrs}$ and second batch of cream was kept in a refrigerator $\left(5\right.$ to $\left.10^{\circ} \mathrm{C}\right)$ for few hours $(3$ to 5 hours) for aging. Butter was prepared from both the batches of cream under standard conditions $\left(9^{\circ} \mathrm{C}\right.$ in summer and $13^{\circ} \mathrm{C}$ in winter) by churning of cream using hand operated butter churn. The butter was then heated on direct flame in a stainless-steel vessel and clarified into ghee with continuous stirring at two different temperatures of $110^{\circ} \mathrm{C} /$ flash and $130^{\circ} \mathrm{C} /$ flash. Ghee was then filtered through 6-8-fold muslin cloth followed by further filtration by using Whatman No.4 filter paper in glass vacuum assembly and finally filled in plastic bottles, cooled to room temperature and kept in a refrigerator at a temperature of 5 to $10^{\circ} \mathrm{C}$ till further analysis.

\section{Analysis}

The color attributes L (lightness (100: white, 0 : black), a (+: red, -: green) and b (+: yellow, -: blue) of ghee samples were measured by Machine vision system Colordesk D1, designed and developed in Dairy Engineering Division, ICAR-NDRI, India. The color measuring system is based on Scilab 5.4, 64 bit platform. Before determining the color value of samples, lights of the instrument were switched on and then molten ghee samples were placed inside the instrument. Images of the samples were taken by the instrument camera and then digital image processing was done by the system and color values of the ghee samples were recorded.

\section{Statistical analysis}

The data obtained in the present study was subjected to one-way analysis of variance (ANOVA) for the significant difference in the samples via Duncan's Multiple Comparison test performed at $95 \%$ confidence interval with SAS software (version 9.3 for windows), San Diego California, USA.

\section{Results and Discussion}

\section{Effect of season on color value in terms of $\mathbf{L}$ (lightness) cow ghee}

The average Lightness Index in different periods of the year of cow ghee and pure buffalo ghee at $110^{\circ} \mathrm{C}$ and $130^{\circ} \mathrm{C}$ are presented in tables (1 and 2). Lightness Index of cow ghee clarified at $110^{\circ} \mathrm{C}$ was highest in the month of December-January (79.02 \pm 1.59$)$ and lowest in month of October-November (76.45 \pm 3.27$)$. Analysis of variance of the data (Table 1) revealed that Lightness Index of cow ghee did not differ significantly. It can also be seen from the table 1 that Lightness Index of cow ghee clarified at $130^{\circ} \mathrm{C}$ was highest in the month of August-September (77.09 \pm 2.25$)$ 
and lowest in month of October-November (75.55 \pm 1.93$)$. Analysis of variance of the data (Table 1) revealed that Lightness Index of cow ghee did not differ significantly. Perusal of the data revealed that in both the cases i.e. ghee clarified at $110^{\circ} \mathrm{C}$ and $130^{\circ} \mathrm{C}$, the effect of season was not observed.

\section{Effect of season on color value in terms of $L$ (lightness) of buffalo ghee}

Lightness Index of buffalo ghee at $110^{\circ} \mathrm{C}$ was highest in the month of February-March $(81.52 \pm 1.272)$ and lowest in month of October-November (76.31 \pm 2.392$)$. Analysis of variance of the data (Table 2) revealed that Lightness Index of buffalo ghee prepared from fresh cream did not differ significantly $(\mathrm{P}=$ $0.05)$. It can also be seen from the table 2 that Lightness Index of buffalo ghee clarified at $130^{\circ} \mathrm{C}$ was highest in the month of AugustSeptember $(81.95 \pm 0.637)$ and lowest in month of October-November (76.81 \pm 1.458$)$. Analysis of variance of the data (Table 2) revealed that Lightness Index of buffalo ghee did not differ significantly $(\mathrm{P}=0.05)$. Perusal of the data revealed that in both the cases i.e. ghee clarified at $110^{\circ} \mathrm{C}$ and $130^{\circ} \mathrm{C}$, the effect of season was not visible.

\section{Effect of temperature of clarification on Color value in terms of $L$ (lightness) of cow and buffalo ghee}

The overall average Lightness Index of cow and buffalo ghee prepared and clarified at $110^{\circ} \mathrm{C}$ and $130^{\circ} \mathrm{C}$ are presented in the table 3. Analysis of variance of the data (Table 3 ) for Lightness Index revealed that pure cow ghee clarified at $110^{\circ} \mathrm{C}$ did not differ significantly $(\mathrm{P}=0.05)$ from the ghee clarified at $130^{\circ} \mathrm{C}$. Similarly the Lightness Index of pure buffalo ghee clarified at $110^{\circ} \mathrm{C}$ did not differ significantly $(\mathrm{P}=0.05)$ from the ghee clarified at $130^{\circ} \mathrm{C}$. Perusal of the data revealed that temperature of clarification did not affect the
Lightness Index of ghee significantly but slight decrease in lightness of cow ghee samples was observed when the clarification temperature was increased whereas in case of buffalo ghee samples slight increase in lightness was observed when clarification temperature was increased.

\section{Effect of ripening on color value in terms of L (lightness) of cow and buffalo ghee}

The overall average of Lightness Index reading along with standard error of cow and buffalo ghee prepared from ripened and fresh cream and clarified at $110^{\circ} \mathrm{C}$ and $130^{\circ} \mathrm{C}$ are presented in table 4. Analysis of variance of the data (Table 4) revealed that Lightness Index of pure cow ghee prepared from ripened cream clarified at $110^{\circ} \mathrm{C}$ did not differ significantly $(\mathrm{P}=0.05)$ from the ghee which was prepared from the fresh cream. Similarly, the Lightness Index of cow ghee prepared from ripened cream and clarified at $130^{\circ} \mathrm{C}$ did not differ significantly $(\mathrm{P}=0.05)$ from the Lightness Index of ghee prepared from fresh cream and clarified at $130^{\circ} \mathrm{C}$. Similarly, in case of buffalo ghee no significant difference $(\mathrm{P}=0.05)$ was observed in Lightness Index of ghee prepared from ripened and fresh cream. Therefore, it can be concluded that ripening of cream before the preparation of ghee did not change the Lightness Index of respective ghee samples significantly.

\section{Effect of season on Color value in terms of 'a' (+: red, -: green) of cow ghee}

Color value in terms of a values signifies that the color of the sample tends toward the greenish tint $(-)$ or redness $(+)$. The average Color value in terms of a value in different periods of the year of cow and buffalo ghee clarified at $110^{\circ} \mathrm{C}$ and $130^{\circ} \mathrm{C}$ are presented in tables 5 and 6 . It can be seen from the table 5 that a values of cow ghee clarified at $110^{\circ} \mathrm{C}$ highest in the month of October-November (- 
$14.58 \pm 0.27)$ and lowest was observed in month of August-September (-21.88 \pm 1.16$)$. Analysis of variance of the data (Table 5) revealed that a values of cow ghee differed significantly $(\mathrm{P}=0.05)$ from other months. It can also be seen from the table 5 that a value of cow ghee clarified at $130^{\circ} \mathrm{C}$ was highest in the month of October-November ($14.38 \pm 0.48)$ and lowest was observed in month of August-September (-24.79 \pm 4.11$)$. Analysis of variance of the data (Table 5) revealed that a values of cow ghee differed significantly $(\mathrm{P}=0.05)$ from other months. Perusal of the data revealed that in both the cases i.e. ghee clarified at $110^{\circ} \mathrm{C}$ and $130^{\circ} \mathrm{C}$, the effect of season was visible and cow ghee samples had greenish tint.

\section{Effect of season on color value in terms of 'a' of LRC buffalo ghee}

It can be seen from the table 6 that a value of buffalo ghee clarified at $110^{\circ} \mathrm{C}$ was highest in the month of February-March $(-5.08 \pm 0.291)$ and lowest was observed in month of December-January (-11.84 \pm 4.068$)$. Analysis of variance of the data (Table 6) revealed that a value of buffalo ghee did not differ significantly $(\mathrm{P}=0.05)$. It can also be seen from table 6 that a value of buffalo ghee clarified at $130^{\circ} \mathrm{C}$ was highest in the month of August-September $(-2.87 \pm 0.973)$ and lowest was observed in month of December-January $(-10.92 \pm 0.924)$.

Analysis of variance of the data (Table 6) revealed that a value of buffalo ghee in August-September differed significantly $(\mathrm{P}=$ 0.05) from other months but a value in October-November, December-January and February-March did not differ significantly. Perusal of the data revealed that in both the cases i.e. ghee clarified at $110^{\circ} \mathrm{C}$ and $130^{\circ} \mathrm{C}$, the effect of season was not visible. Buffalo ghee samples had almost same greenish tint.
Effect of temperature of clarification on Color value in terms of ' $a$ ' of cow and buffalo ghee

The overall average a value of cow and buffalo ghee prepared and clarified at $110^{\circ} \mathrm{C}$ and $130^{\circ} \mathrm{C}$ are presented in table 7 . Analysis of variance of the data (Table 7) for a value revealed that cow ghee clarified at $110^{\circ} \mathrm{C}$ did not differed significantly $(\mathrm{P}=0.05)$ from the ghee clarified at $130^{\circ} \mathrm{C}$. Similarly, the a value of buffalo ghee clarified at $110^{\circ} \mathrm{C}$ did not differ significantly $(\mathrm{P}=0.05)$ from the ghee clarified at $130^{\circ} \mathrm{C}$. Perusal of the data revealed that temperature of clarification did not affect the a value of ghee significantly but slight decrease in greenish tint of cow ghee samples was observed when the clarification temperature was increased whereas in case of buffalo ghee samples slight increase in greenish tint was observed when clarification temperature was increased.

\section{Effect of ripening on color value in terms of ' $a$ ' of cow and buffalo ghee}

The overall average of a value reading along with standard error of cow and buffalo ghee prepared from ripened and fresh cream and clarified at $110^{\circ} \mathrm{C}$ and $130^{\circ} \mathrm{C}$ are presented in Table 8. Analysis of variance of the data (Table 8) revealed that a value of cow ghee prepared from ripened cream clarified at $110^{\circ}$ $\mathrm{C}$ did not differ significantly $(\mathrm{P}=0.05)$ from the ghee which was prepared from the fresh cream. Similarly, a value of cow ghee prepared from ripened cream and clarified at $130^{\circ} \mathrm{C}$ did not differ significantly $(\mathrm{P}=0.05)$ from a value of ghee prepared from fresh cream and clarified at $130^{\circ} \mathrm{C}$. Similarly, in case of buffalo ghee no significant difference $(\mathrm{P}=0.05)$ was observed in a value of ghee prepared from ripened and fresh (fresh) cream. Therefore, it can be concluded that ripening of cream before the preparation of ghee did not change a value of respective ghee samples 
significantly but slight decrease in greenish tint was observed when ripening of cream was done before preparation of ghee samples.

Effect of season on Color value in terms of b (+: yellow, -: blue) of cow ghee

Color value in terms of $b$ signifies that the color of the sample tends toward the bluish tint (-) or yellowness (+). Negative (-) signs signifies that color of sample is towards the bluish color whereas positive (+) sign signifies that color of sample is more towards yellowness. The average Color value in terms of $b$ in different periods of the year of cow and buffalo ghee clarified at $110^{\circ} \mathrm{C}$ and $130^{\circ} \mathrm{C}$ are presented in tables 9 and 10. It can be seen from table 9 that $b$ value of cow ghee clarified at $110^{\circ} \mathrm{C}$ highest in the month of DecemberJanuary (77.56 \pm 1.12$)$ and lowest was observed in month of October-November (66.08 \pm 3.36$)$. Analysis of variance of the data (Table 9) revealed that $b$ value of cow ghee differed significantly $(\mathrm{P}=0.05)$. It can also be seen from table 9 that $b$ value of cow ghee clarified at $130^{\circ} \mathrm{C}$ was highest in the month of December-January $(75.95 \pm 1.78)$ and lowest was observed in month of October-November $(71.29 \pm 1.00)$. Analysis of variance of the data (Table 9) revealed that $b$ value of cow ghee differed significantly $(\mathrm{P}=0.05)$. Perusal of the data revealed that in both cases i.e. ghee clarified at $110^{\circ} \mathrm{C}$ and $130^{\circ} \mathrm{C}$, the effect of season visible. Cow ghee samples have high yellowness and it is attributed to the present of $\beta$-carotene pigment in cow ghee.

\section{Effect of season on Color value in terms of} b (+: yellow, -: blue) of buffalo ghee

It can be seen from table 10 that $b$ value of pure buffalo ghee clarified at $110^{\circ} \mathrm{C}$ was highest in the month of December-January $(11.77 \pm 1.094)$ and lowest was observed in month of August-September (4.40 \pm 3.029$)$. Analysis of variance of the data (Table 10) revealed that $b$ value of buffalo ghee differed significantly $(\mathrm{P}=0.05)$ in December-January, whereas in other months it remains almost same. It can also be seen from table 10 that $b$ value of buffalo ghee clarified at $130^{\circ} \mathrm{C}$ was highest in the month of December-January $(10.31 \pm 1.360)$ and lowest in month of AugustSeptember (3.22 \pm 1.005$)$. Analysis of variance of the data (Table 10) revealed that $b$ value of buffalo ghee differed significantly $(\mathrm{P}=0.05)$. Perusal of the data revealed that in both the cases i.e. ghee clarified at $110^{\circ} \mathrm{C}$ and $130^{\circ} \mathrm{C}$, the effect of season was visible.

\section{Effect of temperature of clarification on Color value in terms of $b$ (+: yellow, -: blue) of cow and buffalo ghee}

The overall average $b$ value of pure cow ghee and pure buffalo ghee prepared and clarified at $110^{\circ} \mathrm{C}$ and $130^{\circ} \mathrm{C}$ are presented in the table 11. Analysis of variance of the data (Table 11) for $b$ value revealed that cow ghee clarified at $110^{\circ} \mathrm{C}$ did not differed significantly $(\mathrm{P}=0.05)$ from the ghee clarified at $130^{\circ}$ C. Similarly, the $b$ value of pure buffalo ghee clarified at $110^{\circ} \mathrm{C}$ did not differ significantly $(\mathrm{P}=0.05)$ from the ghee clarified at $130^{\circ} \mathrm{C}$.

Perusal of the data revealed that temperature of clarification did not affect the $b$ value of ghee significantly. Results obtained in the present study on color value (b) of cow and buffalo ghee are in general agreements with those reported by the earlier workers on ghee (Suwarat and Tungjaroenchai, 2013).

\section{Effect of Ripening on Color value in terms of $b$ of cow and buffalo ghee}

The overall average of $b$ value reading along with standard error of cow and buffalo ghee prepared from ripened and fresh cream and clarified at $110^{\circ} \mathrm{C}$ and $130^{\circ} \mathrm{C}$ are presented in table 12 . 
Table.1 Lightness index of cow ghee at $110^{\circ} \mathrm{C}$ and $130^{\circ} \mathrm{C}$

\begin{tabular}{l|l|l|l|l|l|}
$\begin{array}{l}\text { Temperature } \\
\text { of } \\
\text { Clarification }\end{array}$ & \multicolumn{5}{|c}{ Sample Intervals } \\
\hline $110^{\circ} \mathrm{C}$ & AUG-SEP & OCT-NOV & DEC-JAN & FEB-MAR & CD value (P=0.05) \\
\hline $130^{\circ} \mathrm{C}$ & $77.51 \pm 1.59^{\mathrm{a}}$ & $76.45 \pm 3.27^{\text {a }}$ & $79.02 \pm 1.59^{\mathrm{a}}$ & $78.96 \pm 2.23^{\mathrm{a}}$ & 6.055 \\
\hline & $77.09 \pm 2.25^{\mathrm{a}}$ & $75.55 \pm 2.45^{\mathrm{a}}$ & $75.58 \pm 1.93^{\mathrm{a}}$ & $76.41 \pm 0.52^{\mathrm{a}}$ & 5.164 \\
\hline
\end{tabular}

Mean \pm S.E.M = 3

Values bearing different superscripts in each column differ significantly

Table.2 Lightness index of buffalo ghee at $110^{\circ} \mathrm{C}$ and $130^{\circ} \mathrm{C}$

\begin{tabular}{c|c|c|c|c|c|}
$\begin{array}{c}\text { Temperature } \\
\text { of } \\
\text { Clarification }\end{array}$ & AUG-SEP & OCT-NOV & DEC-JAN & FEB-MAR & $\begin{array}{c}\text { CD value } \\
(\mathrm{P}=0.05)\end{array}$ \\
\hline $110^{\circ} \mathrm{C}$ & $79.42 \pm 2.495^{\mathrm{a}}$ & $76.31 \pm 2.392^{\mathrm{a}}$ & $79.62 \pm 1.407^{\mathrm{a}}$ & $81.52 \pm 1.272^{\mathrm{a}}$ & 5.248 \\
\hline $130^{\circ} \mathrm{C}$ & $80.40 \pm 2.187^{\mathrm{a}}$ & $76.81 \pm 1.458^{\mathrm{a}}$ & $81.95 \pm 0.637^{\mathrm{a}}$ & $77.87 \pm 3.722^{\mathrm{a}}$ & 6.125 \\
\hline
\end{tabular}

Mean \pm S.E.M = 3

Values bearing different superscripts in each column differ significantly

Table.3 Color value in terms of L (lightness) of cow and buffalo ghee clarified at $110^{\circ} \mathrm{C}$ and $130^{\circ} \mathrm{C}$

\begin{tabular}{|c|c|c|}
\hline \multirow{2}{*}{$\begin{array}{c}\text { Temperature of } \\
\text { Clarification }\end{array}$} & \multicolumn{2}{|c|}{ Samples } \\
\hline $110^{\circ} \mathrm{C}$ & COW GHEE & BUFFALO GHEE \\
\hline $130^{\circ} \mathrm{C}$ & $70.81 \pm 3.087^{\mathrm{a}}$ & $73.21 \pm 2.415^{\mathrm{a}}$ \\
\hline $\mathrm{CD}$ value $(\mathrm{P}=0.05)$ & $69.57 \pm 2.704^{\mathrm{a}}$ & $74.09 \pm 2.790^{\mathrm{a}}$ \\
\hline
\end{tabular}

Mean \pm S.E.M $=24$

Values bearing different superscripts in each column differ significantly

Table.4 Color value in terms of L (lightness) of ripened and fresh cow and buffalo ghee clarified at $110^{\circ} \mathrm{C}$ and $130^{\circ} \mathrm{C}$

\begin{tabular}{|c|c|c|c|c|}
\hline \multirow{3}{*}{ Process } & \multicolumn{2}{|c|}{ COW GHEE } & \multicolumn{2}{|c|}{ BUFFALO GHEE } \\
\hline & \multicolumn{2}{|c|}{ Temp. of Clarification } & \multicolumn{2}{|c|}{ Temp. of Clarification } \\
\hline & $110^{\circ} \mathrm{C}$ & $130^{\circ} \mathrm{C}$ & $110^{\circ} \mathrm{C}$ & $130^{\circ} \mathrm{C}$ \\
\hline UNRIPENING & $71.13 \pm 4.671^{\mathrm{a}}$ & $71.99 \pm 3.997^{\mathrm{a}}$ & $72.95 \pm 3.387^{\mathrm{a}}$ & $75.17 \pm 4.247^{\mathrm{a}}$ \\
\hline RIPENING & $70.48 \pm 4.451^{\mathrm{a}}$ & $71.16 \pm 3.995^{\mathrm{a}}$ & $73.46 \pm 0.239^{\mathrm{a}}$ & $73.01 \pm 3.971^{\mathrm{a}}$ \\
\hline $\mathrm{CD}$ value $(\mathrm{P}=0.05)$ & 12.812 & 11.220 & 10.023 & 11.544 \\
\hline
\end{tabular}

Mean \pm S.E.M $=12$

Values bearing different superscripts in each column differ significantly 
Table.5 Color value in terms of 'a' of cow ghee clarified at $110^{\circ} \mathrm{C}$ and $130^{\circ} \mathrm{C}$

\begin{tabular}{l|c|c|c|c|c|}
\hline $\begin{array}{l}\text { Temperature } \\
\text { of } \\
\text { Clarification }\end{array}$ & \multicolumn{5}{|c|}{ Sample Intervals } \\
\cline { 2 - 7 } & AUG-SEP & OCT-NOV & DEC-JAN & FEB-MAR & $\begin{array}{c}\text { CD value } \\
(\mathrm{P}=0.05)\end{array}$ \\
\hline $110^{\circ} \mathrm{C}$ & $-21.88 \pm 1.16^{\mathrm{c}}$ & $-14.58 \pm 0.27^{\mathrm{a}}$ & $-20.82 \pm 1.43^{\mathrm{bc}}$ & $-18.75 \pm 0.83^{\mathrm{b}}$ & 2.71 \\
\hline $130^{\circ} \mathrm{C}$ & $-24.79 \pm 4.11^{\mathrm{b}}$ & $-14.38 \pm 0.48^{\mathrm{a}}$ & $-24.06 \pm 2.65^{\mathrm{ab}}$ & $-22.30 \pm 5.44^{\mathrm{ab}}$ & 9.75 \\
\hline
\end{tabular}

Mean \pm S.E.M $=3$

Values bearing different superscripts in each column differ significantly

Table.6 Color value in terms of 'a' of buffalo ghee clarified at $110^{\circ} \mathrm{C}$ and $130^{\circ} \mathrm{C}$

\begin{tabular}{c|c|c|c|c|c|}
$\begin{array}{c}\text { Temperature } \\
\text { of } \\
\text { Clarification }\end{array}$ & AUG-SEP & OCT-NOV & DEC-JAN & FEB-MAR & $\begin{array}{c}\text { CD value } \\
(\mathrm{P}=0.05)\end{array}$ \\
\hline & & & & & 9.032 \\
\hline $110^{\circ} \mathrm{C}$ & $-5.72 \pm 4.334^{\mathrm{a}}$ & $-8.69 \pm 3.257^{\mathrm{a}}$ & $-11.84 \pm 4.068^{\mathrm{a}}$ & $-5.08 \pm 0.291^{\mathrm{a}}$ & $9.034^{\mathrm{b}}$ \\
\hline $130^{\circ} \mathrm{C}$ & $-2.87 \pm 0.973^{\mathrm{a}}$ & $-10.18 \pm 1.027^{\mathrm{b}}$ & $-10.92 \pm 0.924^{\mathrm{b}}$ & $-7.69 \pm 1.605^{\mathrm{b}}$ & 4.751 \\
\hline
\end{tabular}

Mean \pm S.E.M $=3$

Values bearing different superscripts in each column differ significantly

Table.7 Color value in terms of 'a' of cow and buffalo ghee clarified at $110^{\circ} \mathrm{C}$ and $130^{\circ} \mathrm{C}$

\begin{tabular}{|l|l|l|}
\multicolumn{1}{c}{$\begin{array}{c}\text { Temperature of } \\
\text { Clarification }\end{array}$} & \multicolumn{1}{c|}{ COW GHEE } & \multicolumn{1}{c|}{ Samples } \\
\hline $110^{\circ} \mathrm{C}$ & $-18.89 \pm 0.718^{\mathrm{a}}$ & $-6.14 \pm 0.900^{\mathrm{a}}$ \\
\hline $130^{\circ} \mathrm{C}$ & $-20.90 \pm 1.211^{\mathrm{a}}$ & $-5.46 \pm 0.805^{\mathrm{a}}$ \\
\hline $\mathrm{CD}$ value $(\mathrm{P}=0.05)$ & 2.774 & 2.379 \\
\hline
\end{tabular}

Mean \pm S.E.M $=24$

Values bearing different superscripts in each column differ significantly

Table.8 Color value in terms of ' $a$ ' of ripened and fresh cow and buffalo ghee clarified at $110^{\circ} \mathrm{C}$ and $130^{\circ} \mathrm{C}$

\begin{tabular}{|l|c|c|c|c|}
\multirow{2}{*}{ Process } & \multicolumn{2}{|c|}{ COW GHEE } & \multicolumn{2}{c|}{ BUFFALO GHEE } \\
\cline { 2 - 5 } & \multicolumn{2}{|c|}{ Temp. of Clarification } & \multicolumn{2}{c|}{ Temp. of Clarification } \\
\hline & $110^{\circ} \mathrm{C}$ & $130^{\circ} \mathrm{C}$ & $110^{\circ} \mathrm{C}$ & $130^{\circ} \mathrm{C}$ \\
\hline UNRIPENING & $-18.78 \pm 1.158^{\mathrm{a}}$ & $-20.43 \pm 1.699^{\mathrm{a}}$ & $-4.45 \pm 0.858^{\mathrm{a}}$ & $-3.01 \pm 0.487^{\mathrm{a}}$ \\
\hline RIPENING & $-19.01 \pm 0.954^{\mathrm{a}}$ & $-21.38 \pm 1.865^{\mathrm{a}}$ & $-7.83 \pm 1.495^{\mathrm{a}}$ & $-7.91 \pm 1.185^{\mathrm{a}}$ \\
\hline $\mathrm{CD}$ value $(\mathrm{P}=0.05)$ & 2.979 & 5.0103 & 3.423 & 2.544 \\
\hline
\end{tabular}

Mean \pm S.E.M $=12$

Values bearing different superscripts in each column differ significantly 
Table.9 Color value in terms of b (+: yellow, -: blue) of cow ghee clarified at $110^{\circ} \mathrm{C}$ and $130^{\circ} \mathrm{C}$

\begin{tabular}{l|c|c|c|c|c|}
\hline \multirow{2}{*}{$\begin{array}{l}\text { Temperature } \\
\text { of } \\
\text { Clarification }\end{array}$} & AUG-SEP & OCT-NOV & DEC-JAN & FEB-MAR & $\begin{array}{c}\text { CD value } \\
(\mathrm{P}=0.05)\end{array}$ \\
\cline { 2 - 6 } & $67.58 \pm 0.42^{\mathrm{b}}$ & $66.08 \pm 3.36^{\mathrm{b}}$ & $77.56 \pm 1.12^{\mathrm{a}}$ & $76.85 \pm 1.67^{\mathrm{a}}$ & 5.241 \\
\hline $110^{\circ} \mathrm{C}$ & $73.60 \pm 1.12^{\mathrm{ab}}$ & $71.29 \pm 1.00^{\mathrm{b}}$ & $75.95 \pm 1.78^{\mathrm{a}}$ & $72.10 \pm 0.34^{\mathrm{b}}$ & 3.137 \\
\hline $130^{\circ} \mathrm{C}$ & & & & \\
\hline
\end{tabular}

Mean \pm S.E.M $=3$

Values bearing different superscripts in each column differ significantly

Table.10 Color value in terms of b (+: yellow, -: blue) of buffalo ghee clarified at $110^{\circ} \mathrm{C}$ and $130^{\circ} \mathrm{C}$

\begin{tabular}{|l|c|c|c|c|c|}
\hline \multirow{2}{*}{$\begin{array}{l}\text { Temperature } \\
\text { of } \\
\text { Clarification }\end{array}$} & AUG-SEP & OCT-NOV & DEC-JAN & FEB-MAR & $\begin{array}{c}\text { CD value } \\
(\mathrm{P}=0.05)\end{array}$ \\
\hline $110^{\circ} \mathrm{C}$ & $4.40 \pm 3.029^{\mathrm{b}}$ & $6.09 \pm 1.209^{\mathrm{b}}$ & $11.77 \pm 1.094^{\mathrm{a}}$ & $4.70 \pm 1.345^{\mathrm{b}}$ & 4.917 \\
\hline $130^{\circ} \mathrm{C}$ & $3.22 \pm 1.005^{\mathrm{b}}$ & $6.40 \pm 1.142^{\mathrm{ab}}$ & $10.31 \pm 1.360^{\mathrm{a}}$ & $9.41 \pm 3.730^{\mathrm{a}}$ & 5.660 \\
\hline
\end{tabular}

Mean \pm S.E.M $=3$

Values bearing different superscripts in each column differ significantly

Table.11 Color value in terms of b (+: yellow, -: blue) of cow and buffalo ghee clarified at $110^{\circ}$ $\mathrm{C}$ and $130^{\circ} \mathrm{C}$

\begin{tabular}{|l|c|c|}
\hline $\begin{array}{l}\text { Temperature } \\
\text { Clarification }\end{array}$ & \multicolumn{2}{|c|}{ Samples } \\
\hline $110^{\circ} \mathrm{C}$ & COW GHEE & BUFFALO GHEE \\
\hline $130^{\circ} \mathrm{C}$ & $65.35 \pm 2.944^{\mathrm{a}}$ & $5.69 \pm 0.940^{\mathrm{a}}$ \\
\hline $\mathrm{CD}$ value $(\mathrm{P}=0.05)$ & $63.25 \pm 2.779^{\mathrm{a}}$ & $6.44 \pm 0.793^{\mathrm{a}}$ \\
\hline
\end{tabular}

Mean \pm S.E.M $=24$

Values bearing different superscripts in each column differ significantly

Table.12 Color value in terms of b of ripened and fresh cow and buffalo ghee clarified at $110^{\circ} \mathrm{C}$ and $130^{\circ} \mathrm{C}$

\begin{tabular}{|l|c|c|c|c|}
\multirow{2}{*}{ Process } & \multicolumn{2}{|c|}{ COW GHEE } & \multicolumn{2}{c|}{ BUFFALO GHEE } \\
\cline { 2 - 5 } & \multicolumn{2}{|c|}{ Temp. of Clarification } & \multicolumn{2}{c|}{ Temp. of Clarification } \\
\hline & $110^{\circ} \mathrm{C}$ & $130^{\circ} \mathrm{C}$ & $110^{\circ} \mathrm{C}$ & $130^{\circ} \mathrm{C}$ \\
\hline UNRIPENING & $65.69 \pm 3.437^{\mathrm{a}}$ & $60.28 \pm 3.774^{\mathrm{a}}$ & $4.14 \pm 1.219^{\mathrm{a}}$ & $5.56 \pm 1.109^{\mathrm{a}}$ \\
\hline RIPENING & $65.02 \pm 5.103^{\mathrm{a}}$ & $66.23 \pm 4.216^{\mathrm{a}}$ & $7.24 \pm 1.379^{\mathrm{a}}$ & $7.33 \pm 1.169^{\mathrm{a}}$ \\
\hline $\mathrm{CD}$ value $(\mathrm{P}=0.05)$ & 12.217 & 11.234 & 3.653 & 3.199 \\
\hline
\end{tabular}

Mean \pm S.E.M $=12$

Values bearing different superscripts in each column differ significantly 
Table.13 Yellowness Index of cow ghee clarified at $110^{\circ} \mathrm{C}$ and $130^{\circ} \mathrm{C}$

\begin{tabular}{|l|c|c|c|c|c|}
\hline $\begin{array}{l}\text { Temperature } \\
\text { of } \\
\text { Clarification }\end{array}$ & \multicolumn{5}{|c}{ Sample Intervals } \\
\cline { 2 - 6 } & AUG-SEP & OCT-NOV & DEC-JAN & FEB-MAR & $\begin{array}{c}\text { CD value } \\
(\mathrm{P}=0.05)\end{array}$ \\
\hline $110^{\circ} \mathrm{C}$ & $79.93 \pm 1.15^{\mathrm{b}}$ & $71.13 \pm 4.83^{\mathrm{c}}$ & $86.77 \pm 1.30^{\mathrm{ab}}$ & $88.03 \pm 0.95^{\mathrm{a}}$ & 6.942 \\
\hline $130^{\circ} \mathrm{C}$ & $81.73 \pm 3.35^{\mathrm{a}}$ & $77.53 \pm 1.11^{\mathrm{a}}$ & $84.17 \pm 2.69^{\mathrm{a}}$ & $83.08 \pm 4.46^{\mathrm{a}}$ & 8.375 \\
\hline
\end{tabular}

Mean \pm S.E.M $=3$

Values bearing different superscripts in each column differ significantly

Table.14 Yellowness Index of buffalo ghee clarified at $110^{\circ} \mathrm{C}$ and $130^{\circ} \mathrm{C}$

\begin{tabular}{l|l|l|l|l|l|}
$\begin{array}{l}\text { Temperature } \\
\text { of } \\
\text { Clarification }\end{array}$ & AUG-SEP & OCT-NOV & DEC-JAN & FEB-MAR & $\begin{array}{c}\text { CD value } \\
(\mathrm{P}=0.05)\end{array}$ \\
\hline $110^{\circ} \mathrm{C}$ & $8.01 \pm 3.733^{\mathrm{a}}$ & $9.09 \pm 2.111^{\mathrm{a}}$ & $14.38 \pm 1.310^{\mathrm{a}}$ & $11.00 \pm 2.307^{\mathrm{a}}$ & 6.714 \\
\hline $130^{\circ} \mathrm{C}$ & $7.72 \pm 3.912^{\mathrm{a}}$ & $11.68 \pm 2.157^{\mathrm{a}}$ & $12.67 \pm 0.321^{\mathrm{a}}$ & $14.16 \pm 6.114^{\mathrm{a}}$ & 10.09 \\
\hline
\end{tabular}

Mean \pm S.E.M $=3$

Values bearing different superscripts in each column differ significantly

Table.15 Yellowness Index of cow and buffalo ghee clarified at $110^{\circ} \mathrm{C}$ and $130^{\circ} \mathrm{C}$

\begin{tabular}{|c|}
\hline $\begin{array}{c}\text { Temperature of } \\
\text { Clarification }\end{array}$ \\
\hline $110^{\circ} \mathrm{C}$ \\
\hline $130^{\circ} \mathrm{C}$ \\
\hline $\mathrm{CD}$ value $(\mathrm{P}=0.05)$ \\
\hline
\end{tabular}

\begin{tabular}{|c|c|}
\hline \multicolumn{2}{|c|}{ Samples } \\
\hline COW GHEE & BUFFALO GHEE \\
\hline $82.28 \pm 1.205^{\mathrm{a}}$ & $11.37 \pm 2.005^{\mathrm{a}}$ \\
\hline $79.12 \pm 1.098^{\mathrm{a}}$ & $14.14 \pm 2.138^{\mathrm{a}}$ \\
\hline 3.211 & 5.775 \\
\hline
\end{tabular}

Mean \pm S.E.M $=24$

Values bearing different superscripts in each column differ significantly

Table.16 Yellowness Index of ripened and fresh cow and buffalo ghee clarified at $110^{\circ} \mathrm{C}$ and $130^{\circ} \mathrm{C}$

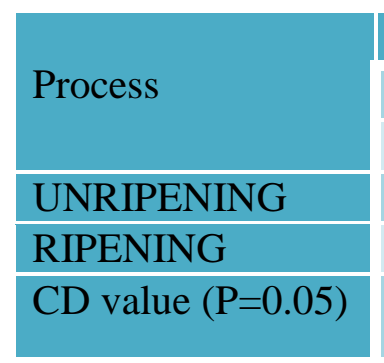

\begin{tabular}{|c|c|c|c|}
\hline \multicolumn{2}{|c|}{ COW GHEE } & \multicolumn{3}{|c|}{ BUFFALO GHEE } \\
\hline \multicolumn{2}{|c|}{ Temp. of Clarification } & \multicolumn{2}{|c|}{ Temp. of Clarification } \\
\hline $110^{\circ} \mathrm{C}$ & $130^{\circ} \mathrm{C}$ & $110^{\circ} \mathrm{C}$ & $130^{\circ} \mathrm{C}$ \\
\hline $83.10 \pm 0.916^{\mathrm{a}}$ & $76.63 \pm 1.447^{\mathrm{a}}$ & $10.12 \pm 3.628^{\mathrm{a}}$ & $14.71 \pm 4.040^{\mathrm{a}}$ \\
\hline $81.47 \pm 2.318^{\mathrm{a}}$ & $81.63 \pm 1.392^{\mathrm{a}}$ & $12.62 \pm 2.025^{\mathrm{a}}$ & $13.56 \pm 1.897^{\mathrm{a}}$ \\
\hline 4.948 & 3.986 & 8.250 & 8.861 \\
\hline
\end{tabular}

Mean \pm S.E.M $=12$

Values bearing different superscripts in each column differ significantly 
Table.17 Whiteness Index of cow clarified at $110^{\circ} \mathrm{C}$ and $130^{\circ} \mathrm{C}$

\begin{tabular}{|l|c|c|c|c|c|}
\hline \multirow{2}{*}{$\begin{array}{c}\text { Temperature } \\
\text { of } \\
\text { Clarification }\end{array}$} & AUG-SEP & OCT-NOV & DEC-JAN & FEB-MAR & $\begin{array}{c}\text { CD value } \\
(\mathrm{P}=0.05)\end{array}$ \\
\hline $110^{\circ} \mathrm{C}$ & $21.45 \pm 0.26^{\mathrm{a}}$ & $21.55 \pm 2.69^{\mathrm{a}}$ & $16.95 \pm 0.38^{\mathrm{b}}$ & $18.08 \pm 0.79^{\mathrm{ab}}$ & 3.786 \\
\hline $130^{\circ} \mathrm{C}$ & $18.85 \pm 0.93^{\mathrm{ab}}$ & $21.45 \pm 1.71^{\mathrm{a}}$ & $16.57 \pm 0.31^{\mathrm{b}}$ & $20.69 \pm 1.49^{\mathrm{a}}$ & 3.289 \\
\hline
\end{tabular}

Mean \pm S.E.M $=3$

Values bearing different superscripts in each column differ significantly

Table.18 Whiteness Index of buffalo ghee clarified at $110^{\circ} \mathrm{C}$ and $130^{\circ} \mathrm{C}$

\begin{tabular}{|l|c|c|c|c|c|}
\hline \multirow{2}{*}{$\begin{array}{l}\text { Temperature } \\
\text { of } \\
\text { Clarification }\end{array}$} & AUG-SEP & OCT-NOV & DEC-JAN & FEB-MAR & $\begin{array}{c}\text { CD value } \\
(\mathrm{P}=0.05)\end{array}$ \\
\hline $110^{\circ} \mathrm{C}$ & $77.76 \pm 4.289^{\mathrm{a}}$ & $71.98 \pm 2.785^{\mathrm{a}}$ & $72.50 \pm 3.390^{\mathrm{a}}$ & $80.16 \pm 0.757^{\mathrm{a}}$ & 8.230 \\
\hline $130^{\circ} \mathrm{C}$ & $79.82 \pm 1.875^{\mathrm{a}}$ & $73.31 \pm 1.751^{\mathrm{a}}$ & $76.33 \pm 1.888^{\mathrm{a}}$ & $74.59 \pm 4.902^{\mathrm{a}}$ & 7.783 \\
\hline
\end{tabular}

Mean \pm S.E.M $=3$

Values bearing different superscripts in each column differ significantly

Table.19 Whiteness Index of cow and buffalo ghee clarified at $110^{\circ} \mathrm{C}$ and $130^{\circ} \mathrm{C}$

\begin{tabular}{|c|c|c|}
\hline \multirow{2}{*}{$\begin{array}{l}\text { Temperature of } \\
\text { Clarification }\end{array}$} & \multicolumn{2}{|c|}{ Samples } \\
\hline & COW GHEE & BUFFALO GHEE \\
\hline $110^{\circ} \mathrm{C}$ & $22.90 \pm 1.065^{\mathrm{a}}$ & $71.30 \pm 2.437^{\mathrm{a}}$ \\
\hline $130^{\circ} \mathrm{C}$ & $24.21 \pm 1.206^{\mathrm{a}}$ & $72.27 \pm 2.802^{\mathrm{a}}$ \\
\hline $\mathrm{CD}$ value $(\mathrm{P}=0.05)$ & 3.171 & 7.317 \\
\hline
\end{tabular}

Mean \pm S.E. $M=24$

Values bearing different superscripts in each column differ significantly

Table.20 Whiteness Index of ripened and fresh cow and buffalo ghee at $110^{\circ} \mathrm{C}$ and $130^{\circ} \mathrm{C}$

\begin{tabular}{|c|c|c|c|c|}
\hline \multirow{3}{*}{ Process } & \multicolumn{2}{|c|}{ COW GHEE } & \multicolumn{2}{|c|}{ BUFFALO GHEE } \\
\hline & \multicolumn{2}{|c|}{ Temp. of Clarification } & \multicolumn{2}{|c|}{ Temp. of Clarification } \\
\hline & $110^{\circ} \mathrm{C}$ & $130^{\circ} \mathrm{C}$ & $110^{\circ} \mathrm{C}$ & $130^{\circ} \mathrm{C}$ \\
\hline UNRIPENING & $22.55 \pm 0.869^{a}$ & $26.80 \pm 1.435^{\mathrm{a}}$ & $71.98 \pm 3.518^{a}$ & $74.28 \pm 4.346^{\mathrm{a}}$ \\
\hline RIPENING & $23.26 \pm 2.044^{\mathrm{a}}$ & $21.64 \pm 1.726^{\mathrm{a}}$ & $70.60 \pm 3.672^{a}$ & $70.26 \pm 3.827^{\mathrm{a}}$ \\
\hline $\begin{array}{l}\mathrm{CD} \\
\text { value }(\mathrm{P}=0.05)\end{array}$ & 4.409 & 4.457 & 10.097 & 11.498 \\
\hline
\end{tabular}

Mean \pm S.E.M $=12$

Values bearing different superscripts in each column differ significantly 
Analysis of variance of the data (Table 12) revealed that $b$ value of cow ghee prepared from ripened cream clarified at $110^{\circ} \mathrm{C}$ did not differ significantly $(\mathrm{P}=0.05)$ from the ghee which was prepared from the fresh cream. Similarly, the b value of cow ghee prepared from ripened cream and clarified at $130^{\circ} \mathrm{C}$ did not differ significantly $(\mathrm{P}=0.05)$ from the $\mathrm{b}$ value of ghee prepared from fresh cream and clarified at $130^{\circ} \mathrm{C}$. Similarly, in case of buffalo ghee no significant difference $(\mathrm{P}=0.05)$ was observed in $\mathrm{b}$ value of ghee prepared from ripened and fresh (fresh) cream. Therefore, it can be concluded that ripening of cream before the preparation of ghee did not change the $b$ value of respective ghee samples significantly.

\section{Effect of season on yellowness Index of cow ghee}

The average Yellowness Index in different periods of the year of cow and buffalo ghee clarified at $110^{\circ} \mathrm{C}$ and $130^{\circ} \mathrm{C}$ are presented in tables 13 and 14. It can be seen from table 13 that Yellowness Index of cow ghee clarified at $110^{\circ} \mathrm{C}$ highest in the month of FebruaryMarch (88.03 \pm 0.95$)$ which was almost similar to the December-January $(86.77 \pm 1.30)$ and lowest in month of October-November $(71.13 \pm 4.83)$. Analysis of variance of the data (Table 13) revealed that Yellowness Index of cow ghee differed significantly $(\mathrm{P}=0.05)$. It can also be seen from table 13 that Yellowness Index of cow ghee clarified at $130^{\circ} \mathrm{C}$ was highest in the month of December-January $(84.17 \pm 2.69)$ which was almost similar to the August-September $(81.73 \pm 3.35)$ and February-March $(83.08 \pm 4.46)$ and lowest was observed in month of October-November $(77.53 \pm 1.11)$. Analysis of variance of the data (Table 13) revealed that Yellowness Index of cow did not differ significantly $(\mathrm{P}=0.05)$. Perusal of the data revealed that in case of ghee clarified at $110^{\circ} \mathrm{C}$ effect of season was visible but in case of ghee clarified at $130^{\circ} \mathrm{C}$, the effect of season was not visible. Cow ghee samples have high yellowness and it is attributed to the present of $\beta$-carotene pigment in cow ghee.

\section{Effect of season on Yellowness Index of buffalo ghee}

It can be seen from table 14 that Yellowness Index of buffalo ghee clarified at $110^{\circ} \mathrm{C}$ was highest in the month of December-January $(14.38 \pm 1.310)$ and lowest was observed in month of August-September (8.01 \pm 3.733$)$. Analysis of variance of the data (Table 14) revealed that Yellowness Index of pure buffalo ghee did not differ significantly $(\mathrm{P}=$ $0.05)$. It can also be seen from table 14 that Yellowness Index of buffalo ghee clarified at $130^{\circ} \mathrm{C}$ was highest in the month of FebruaryMarch (14.16 \pm 6.114$)$ and lowest in month of August-September (7.72 \pm 3.912$)$. Analysis of variance of the data (Table 14) revealed that Yellowness Index of buffalo ghee prepared from ripened cream did not differ significantly $(\mathrm{P}=0.05)$. Perusal of the data revealed that in both the cases i.e. ghee clarified at $110^{\circ} \mathrm{C}$ and $130^{\circ} \mathrm{C}$, the effect of season was not visible. Yellowness Index was more for cow ghee as compared to buffalo ghee. This is due to the yellow color of cow milk fat, which is contributed by fat soluble carotenoids (Palmer and Eckles, 1914).

\section{Effect of temperature of clarification on yellowness index of cow and buffalo ghee}

The overall average Yellowness Index of cow and pure buffalo ghee prepared and clarified at $110^{\circ} \mathrm{C}$ and $130^{\circ} \mathrm{C}$ are presented in table 15. Analysis of variance of the data (Table 15) for Yellowness Index revealed that cow ghee clarified at $110^{\circ} \mathrm{C}$ did not differed significantly $(\mathrm{P}=0.05)$ from the ghee clarified at $130^{\circ} \mathrm{C}$. Similarly the Yellowness Index of buffalo ghee clarified at $110^{\circ} \mathrm{C}$ did not differ 
significantly $(\mathrm{P}=0.05)$ from the ghee clarified at $130^{\circ} \mathrm{C}$. Perusal of the data revealed that temperature of clarification did not affect the Yellowness Index of ghee significantly but slight decrease in yellowness of cow ghee samples was observed when the clarification temperature was increased whereas in case of buffalo ghee samples slight increase in yellowness was observed when clarification temperature was increased.

\section{Effect of ripening on yellowness index of cow and buffalo ghee}

The overall average of Yellowness Index reading along with standard error of cow and buffalo ghee prepared from ripened and fresh cream and clarified at $110^{\circ} \mathrm{C}$ and $130^{\circ} \mathrm{C}$ are presented in table 16. Analysis of variance of the data (Table 16) revealed that Yellowness Index of cow ghee prepared from ripened cream clarified at $110^{\circ} \mathrm{C}$ did not differ significantly $(\mathrm{P}=0.05)$ from the ghee which was prepared from the fresh cream. Similarly, the Yellowness Index of cow ghee prepared from ripened cream and clarified at $130^{\circ} \mathrm{C}$ did not differ significantly $(\mathrm{P}=0.05)$ from the Yellowness Index of ghee prepared from fresh cream and clarified at $130^{\circ}$ C. Similarly, in case of buffalo ghee no significant difference $(\mathrm{P}=0.05)$ was observed in Yellowness Index of ghee prepared from ripened and fresh cream. Therefore, it can be concluded that ripening of cream before the preparation of ghee did not change the Yellowness Index of respective ghee samples significantly.

\section{Effect of season on whiteness index of cow ghee}

The average Whiteness Index in different periods of the year of cow and pure buffalo ghee clarified at $110^{\circ} \mathrm{C}$ and $130^{\circ} \mathrm{C}$ are presented in tables 17 and 18 . It can be seen from table 17 that Whiteness Index of cow ghee clarified at $110^{\circ} \mathrm{C}$ highest in the month of October-November (21.55 \pm 2.69$)$ and lowest in month of December-January (16.95 \pm 0.38$)$. Analysis of variance of the data (Table 17) revealed that Whiteness Index of cow ghee differed significantly $(\mathrm{P}=0.05)$. It can also be seen from table 17 that Whiteness Index of cow ghee clarified at $130^{\circ} \mathrm{C}$ was highest in the month of October-November $(21.45 \pm 1.71)$ lowest in month of DecemberJanuary (16.57 \pm 0.31$)$. Analysis of variance of the data (Table 17) revealed that Whiteness Index of cow ghee differed significantly $(\mathrm{P}=$ $0.05)$. Perusal of the data revealed that in both the cases i.e. ghee clarified at $110^{\circ} \mathrm{C}$ and $130^{\circ}$ $\mathrm{C}$, the effect of season was visible.

\section{Effect of season on whiteness index of buffalo ghee}

Whiteness Index of buffalo ghee clarified at $110^{\circ} \mathrm{C}$ was highest in the month of FebruaryMarch (80.16 \pm 0.757$)$ and lowest in month of October-November (71.98 \pm 2.785$)$. Analysis of variance of the data (Table 18) revealed that Whiteness Index of buffalo ghee did not differ significantly $(\mathrm{P}=0.05)$. It can also be seen from table 18 that Whiteness Index of buffalo ghee clarified at $130^{\circ} \mathrm{C}$ was highest in the month of August-September (79.82 \pm 1.875$)$ and lowest in month of October-November (73.31 \pm 1.751$)$. Analysis of variance of the data (Table 18) revealed that Whiteness Index of buffalo ghee did not differ significantly $(\mathrm{P}=0.05)$. Perusal of the data revealed that in both the cases i.e. ghee clarified at $110^{\circ} \mathrm{C}$ and $130^{\circ} \mathrm{C}$, the effect of season was not visible.

Whiteness Index of buffalo ghee was due to the absence of carotenoids and possibly presence of biliverdin and bilirubin which gave a greenish tint (Suwarat and Tungjaroenchai, 2013; Daniel, 1977; Rao and Dastur, 1984).

Effect of temperature of clarification on Whiteness Index of cow and buffalo ghee 
The overall average Whiteness Index of cow and buffalo ghee prepared and clarified at $110^{\circ} \mathrm{C}$ and $130^{\circ} \mathrm{C}$ are presented in table 19. Analysis of variance of the data (Table 19) for Whiteness Index revealed that cow ghee clarified at $110^{\circ} \mathrm{C}$ did not differed significantly $(\mathrm{P}=0.05)$ from the ghee clarified at $130^{\circ} \mathrm{C}$. Similarly, the Whiteness Index of buffalo ghee clarified at $110^{\circ} \mathrm{C}$ did not differ significantly $(\mathrm{P}=0.05)$ from the ghee clarified at $130^{\circ} \mathrm{C}$. Perusal of the data revealed that temperature of clarification did not affect the Whiteness Index of ghee significantly.

\section{Effect of ripening on whiteness index of pure cow and buffalo ghee}

The overall average of Whiteness Index reading along with standard error of cow and buffalo ghee prepared from ripened and fresh cream and clarified at $110^{\circ} \mathrm{C}$ and $130^{\circ} \mathrm{C}$ are presented in table 20. Analysis of variance of the data (Table 20) revealed that Whiteness Index of cow ghee prepared from ripened cream clarified at $110^{\circ} \mathrm{C}$ did not differ significantly $(\mathrm{P}=0.05)$ from the ghee which was prepared from the fresh cream. Similarly, the Whiteness Index of cow ghee prepared from ripened cream and clarified at $130^{\circ} \mathrm{C}$ did not differ significantly $(\mathrm{P}=0.05)$ from the Whiteness Index of ghee prepared from fresh cream and clarified at $130^{\circ} \mathrm{C}$. Similarly, in case of buffalo ghee no significant difference $(\mathrm{P}=0.05)$ was observed in Whiteness Index of ghee prepared from ripened and fresh cream. Therefore, it can be concluded that ripening of cream before the preparation of ghee did not change the Whiteness Index of respective ghee samples significantly.

From study, it was found that effect of season did not make any significant difference on the color value (L) and Whiteness Index whereas effect of season was visible on the color value (a) and (b) and Yellowness Index. No significant effect of ripening of cream and clarification temperature was observed on color value of ghee samples. Color Value analysis of the cow and buffalo ghee samples revealed that luminance was almost similar for both cow and buffalo ghee. High greenish tint was obtained in buffalo ghee as compare to cow ghee. It was also observed that yellowness index was high in cow ghee samples and low in buffalo ghee samples and vice-versa for whiteness index. It was revealed from the study that with increase in clarification temperature yellowness index decreased and whiteness index increased.

\section{References}

Daniel, E.V. 1977. Study of the changes in milk constituents during the preparation of ghee from sour milk. PhD Thesis, Punjab University, Chandigarh.

De, S. 2010. Indian dairy products. Outlines of Dairy Technology. Oxford University Press, New Delhi. 382-466.

Palmer, L.S., and Eckles, C.H. 1914. Carotinthe principal natural yellow pigment of milk fat: its relations to plant carotin and the carotin of the blood serum, body fat and corpus luteum. Journal of Biological Chemisty. 17: 237-243.

Pawar, N., Gandhi, K., Purohit, A., Arora, S., and Singh, R.R.B. 2014. Effect of added herb extracts on oxidative stability of ghee (butter oil) during accelerated oxidation condition. J. Food Sci. Technol., 2727-2733.

Rajorhia, G.S. 1993. Ghee. In: Macrae R, Robinson RK, Sadler MJ (Ed) Encyclopaedia of Food Science, Food Technology and Nutrition, D.H. Hill.288 3-2889.

Rangappa, K.S., and Achaya, K.T. 1974. Indian dairy products. Asia Publishing House, Mysore. 255-326

Rao, R., and Dastur, N.N. 1984. Association of biliverdin with micellar casein and 
casein fraction of buffalo milk. Indian J. Dairy Sci. 37:234-240.

Suwarat, N., and Tungjaroenchai, W. 2013. Characteristic of ghee obtained from different post-clarification temperatures. International Journal of Bioscience, Biochemistry and Bioinformatics. 3(4).

\section{How to cite this article:}

Sonia Mor, Vivek Sharma, P.S. Minz and Navdeep Nain. 2018. Effect of Season, Heat Clarification Temperature and Ripening of Cream on Color Parameters of Ghee. Int.J.Curr.Microbiol.App.Sci. 7(10): 30-43. doi: https://doi.org/10.20546/ijcmas.2018.710.005 